\title{
Michèle Roberts: Female Genius and the Theology of an English Novelist
}

\section{ABSTRACT}

Since Simone de Beauvoir published The Second Sex in 1949, feminist analysis has tended to assume that the conditions of male normativityreducing woman to the merely excluded "Other" of man-holds true in the experience of all women, not the least, women in the context of Christian praxis and theology. Beauvoir's powerful analysis-showing us how problematic it is to establish a position outside patriarchy's dominance of our conceptual fields-has helped to explain the resilience of sexism and forms of male violence that continue to diminish and destroy women's lives because they cannot be seen as questionable. It has also, I would argue, had the unintended consequence of intensifying the sense of limitation, so that it becomes problematic to account for the work and lives of effective, innovative and responsible women in these contexts. In order to address this problematic issue, I use the life and work of novelist Michèle Roberts, as a case study in female genius within an interdisciplinary field, in order to acknowledge the conditions that have limited a singular woman's literary and theological aspirations but also to claim that she is able to give voice to something creative of her own.

The key concept of female genius within this project draws on Julia Kristeva's notion of being a subject without implicitly excluding embodiment and female desire as in normative male theology, or in notions of genius derived from Romanticism. Roberts' work as a writer qualifies her as female genius in so far as it challenges aspects of traditional Christianity, bringing to birth new relationships between theological themes and scriptural narratives without excluding her singular female desires and pleasures as a writer. This paper-as part of a more inclusive, historical survey of the work of women writers crossing the disciplinary boundaries between literature and Christian theology over the last 
several centuries ${ }^{1}$ also asks whether, in order to do proper justice to the real and proven limitations imposed on countless women in these fields across global and historical contexts, we need, at the same time, to reduce the Christian tradition to something that is always antithetical or for which women can take absolutely no credit or bear no responsibility.

\section{ABstract}

Then it seemed to her she was in her cell, watching the cocoon crack open. Out struggled a creature with great wet, dragging wings that were stuck together. It twitched and flared. Shook out flags of billowing colour, reared its head... she woke up screaming, convinced she was going to die. Not a nightmare but real. The great wings beating above her, the hot pulse of its desire, so close, the fireball eyes staring into hers.

The butterfly filled the tiny room. It trembled. It was ready. At last she realised it had come out of herself. (Roberts, Impossible Saints 35-36)

\section{Female Genius}

Today, an understanding of "genius", originating in the period and style of European culture and thought known as "Romanticism", remains definitive (Battersby 104). This frames "genius" as a typically masculine quality that, when it is associated with women, takes on all the implications of freakishness or madness (Battersby 128-30). In coining the term "female genius" 2 as a way of expressing the idea that, in spite of normative frameworks, women can achieve in their own name, Julia Kristeva concedes that they will be limited by masculinist thinking and patriarchal institutions. Nevertheless, she rejects the idea that woman is excluded from the category of genius by definition and she resists this gendering of genius as exclusively masculine in two ways:

1 This paper forms a part of a larger project in which the idea of female genius is used as a means critically to analyse the theological work of other English women writers from the $17^{\text {th }}, 18^{\text {th }}$ and $19 / 20^{\text {th }}$ centuries. See, Jasper, Alison, Female Genius And Women Doing Theology: Four Historical Cases In The Western Tradition, (Waco, TX, forthcoming).

2 Julia Kristeva's ideas about female genius are laid out in three volumes called, collectively, Female Genius: Life, Madness, Words-Hannah Arendt, Melanie Klein, Colette, a trilogy by Julia Kristeva and published by Columbia University Press in the European Perspectives series. 
(i) The first way has to do with how she understands the development of the human subject as a speaking subject. She rests her account of this speaking subject on a psycholinguistic description (Sjöholm 16-22) in which the interplay of gendered dimensions of the psyche remain, in an optimal sense, continually and productively in play. The maternal body in this context, rather than being seen as a kind of trap for women as Simone de Beauvoir had understood it, constitutes a point of pivotal significance straddling the divide between nature and culture (Sjöholm 57) forming a part of the signifying process itself; "not a murky undercurrent of language, but an aspect of it" (Sjöholm 22). If differentiated male and female identified elements are essential to the development of the subject and neither, in the optimal sense that produces forms of symbolic representation and language, overwhelms the other, then the development of the subject itself cannot be relied upon to support cultural hierarchies or sexist theory and practice.

(ii) Secondly Kristeva opens up the idea of genius to a much wider range of activities or modes of being including elements of embodiment and female desire that are excluded in traditional and normatively masculine theology or from dominant western notions of genius derived substantially from European Romanticism (Battersby 15). Women are female geniuses because they are artists, writers and human beings alongside men and in their own right but not through the conventional exclusion, for example, of their maternal emotions or their female desires. This definition of female genius opens up the field of possibilities to many women, both living and dead who have been geniuses in every context not excluding the maternal (Kristeva, Arendt xv).

At the end of her trilogy on female genius, Kristeva distinguishes three characteristics which can be related to the work and lives of the three women she has designated as such: Hannah Arendt, Melanie Klein and Colette. These characteristics focus on a recognition evidenced in all they do and write of the key sense in which the "ego is inseparable from the variety of its relationships" (Colette 420), the need to "[tend] to the capacity for thought" (Colette 421) and a capacity for birth or rebirth in the sense of bringing about new beginnings (Colette 422-23).

To summarize: Julia Kristeva's notion of female genius is grounded in the feminist theory Simone de Beauvoir initiated in 1949 in The Second Sex, in spite of her own lack of confidence in a woman's ability to achieve this accolade (Second Sex 722-23). It builds on Beauvoir's conviction that genius and a woman's ability to take up the position of subject, are closely related (Second Sex 723), but proposes a complete transformation of the term "genius" making this a possibility for women doing traditionally "womanly" things as well as excelling in those fields and accomplishments normatively reserved to men. The female genius, as Kristeva understands 
her, lives a singular life, distinguishable from other lives by its unique circumstances which include limitations imposed by patriarchal and masculinist structures but which do not thereby exclude her from female genius by definition. The creativity of female geniuses, as Kristeva sees them, fosters relationships; physical, sexual and emotional according to longstanding female association, certainly, but also in all other possible fields. The achievement of this subject position, that for Kristeva is inextricably bound up with the female-identified body's motions and drives, tends to the capacity for thought, and can find expression through the pleasures and pains of bringing into being-giving birth to-children, relationships, language and other forms of symbolic representation; from parcour, pantomime and finding the optimum life/work balance, to set theory or econometrics. The birth or rebirth of insights, motions and movements this generates may indeed change worlds - as Beauvoir's insights have changed worldsor no less significantly, it may transform a single life; that of the female genius herself. In sum we could say that female geniuses resist manufactured pleasures-whether they are made seductive by virtue of their cheapness and availability like fast food and commercial TV, or imposed on them by authoritarian forms of politics and religion that seek to contain or marginalize women and "the feminine". They are wary of standardized banalities that are as unrewarding as they are undemanding of thought and which ultimately cannot save us from the maladies of our souls ${ }^{3}$ and they distinguish between unique pleasures accessible through those things a woman brings into being and tailors or births for herself in singular circumstances, and merely accepting what temporarily distracts or appeases her, ${ }^{4}$ or suits the convenience of the normative, male culture in which she lives.

\section{MiChÈLE RoBerTS}

Michèle Roberts was born in 1949 and brought up in the London suburb of Edgware. Her mother was a French Roman Catholic and she attended Roman Catholic schools in London, before going to University in Oxford in 1967, to study English literature. After graduating, she intended to train as a librarian but instead she fell in love (Roberts, Paper Houses 35) with feminism and committed herself to the life of a writer and feminist activist in London. To date, she has written fourteen novels and three collections of poetry as well as works of non-fiction. She won the Booker Prize in 1992 for Daughters of the House and was made Chevalier de L'Ordre des

See, for example, Kristeva, New Maladies (6-10).

4 See further discussion of this theme in Kristeva's work in Jasper 'Revolting Fantasies' (212, note 7). 
Arts et des Lettres by the French government. She is Emeritus Professor of Creative Writing at the University of East Anglia, UK. She is presented here as a case study for female genius-as defined above-in respect of her life, literary work, but also in respect of what I would call her theology. The idea of the female theologian continues in many circles to be framed as improper; Christian theology is the province of the ordained clergy or the divinely inspired male minister, and a woman's place is not to teach or have authority over men, nor to tell the powerful theological story for herself. ${ }^{5}$ She had better confine herself to literature, for example; an acceptable field for women precisely because it has been seen to require the guiding masculine hand of theology or philosophy to gain legitimacy (Walton, Imagining Theology 34-48). However, within a theological culture that continues to be viewed as normatively male, Roberts exemplifies the female genius who works and creates in pursuit of her desires-including her desire to understand and communicate with God-without bracketing off all she is as a woman.

Roberts exemplifies Kristeva's view that values are not static or frozen standards but that it is in the process of tending to the-maternally instigated-capacity for thought by calling them into question, whether on the level of the individual's psychic life or in relation to societies at large, that they acquire "a sense of mobility, polyvalence and life" (Kristeva, Revolt, She Said 12). So, in Roberts' novels and poetry, prefaces and introductions, as well as in her autobiographical Paper Houses, she generates a sense of mobility, polyvalence and life, by vigorously challenging what she experiences as the static immobility of traditional institutions-for example, patriarchal attitudes towards women as they are enshrined within the Roman Catholic Church's teaching and practice. Her singular practices of writing challenge its theological structures and cast the nature of God's relationship with the world in terms of conceptual and social relationships she fashions for herself as a woman. She questions notions of God as disembodied male and body as sacrificial, expendable and female, through the sensual evocations of carefully crafted words that produce, for example, a God who is " ... not Father, not Lord and King”, but " . . blackness, darkness, sweetness, limited to no one shape but part of everything ...” (Impossible Saints 182) Roberts' representation of God distances her from early Christian, patristic disputes coloured by both Hebrew scripture and classical philosophy. However, her sensual evocations of a God are rooted in her protagonist's—and surely also her own—childhood memories of

5 Traditionalist typically refer to the Pauline or pseudo Pauline books of the New Testament, for example 1 Timothy 2:11-15; 1 Corinthians 14:33-36; Ephesians 5:22-24; Colossians 3:18; 1 Corinthians 11:3-16. 
Catholic Christian worship: “ . . with its brilliantly-lit choir slung with gleaming lamps, its gaudy plaster and gilt decoration, its shrill-voiced choir ... its hideous and lifelike crucifix whose Christ drew your eyes with his nailed body arched and twisted in agony ..." (Impossible Saints 182) The values of the past are not being swept away in individualistic, solipsistic disregard but rigorously interrogated in the light of a different kind of community; one that includes rather than excludes women and what they have been cast to represent within a masculinist economy.

However, this is not to suggest that it is simply because she identifies herself as a feminist, challenging patriarchal Christianity, that she can be accounted as a female genius, but rather to claim her as such because, in a context within which she is primed to respond in accordance to values and frameworks-be they Roman Catholic, masculinist, bourgeois-she brings something new to birth through the exercise of thought, bringing values into question in a process in which her female, embodied desire has not been bracketed off from the start. Writing in the "white heat" of early second wave feminist thinking, Roberts has a different take on Christianity from earlier women and some sharp new analytic tools to use. But I would argue that the nature of her female genius depends more on how she uses those tools than in their specific character as "feminist".

Aligning myself with Kristeva and against Beauvoir's despairing dismissal of women's claim to genius (Second Sex 723), my argument is that the achievements of women cannot be reduced to mirroring and silence, even within the especially contentious context of Christian theology and praxis. By writing novels with identifiably Christian themes, Roberts gives herself room to look at what was at stake. Her embodiment and desire are brought into account in order to pose that question and to explore sacred scripture and ecclesiastical power outside the Church's sanctified roles of ordained clergy or professed religious. In other words, her voice could not be silenced by what Beauvoir called the female situation or condition. ${ }^{6}$ With Kristeva, I would say that Roberts did not wait for the female condition to evolve; ". . . in order to realize [her] freedom: is not "genius" precisely that breach through and beyond the "situation"? (Colette 407).

Of course we cannot sweep aside Beauvoir's reflections on the female situation. To say that Roberts was able to write and thus to live, is not to suggest that the Curia of the Roman Catholic Church was going to take her views seriously. Neither can we say that this would not frustrate or limit her in any way. Roberts had invested a great deal in the life of the Church; she had been intensely religious as a child and adolescent (Paper Houses 5). In her last years at school, she had even thought about joining

${ }^{6}$ See for example, Beauvoir, Second Sex (608-40). 
a religious order. But in her late teens she broke with the Church, unable to accept any longer what she saw as its attempts to control the expression of her female sexuality (Secret Gospel 9) ${ }^{7}$ or her passion for knowledge (Paper Houses 11). Yet though she views herself in adulthood as an atheist, as a mature writer she still admits the significance of her connections with the Roman Catholic Church's attitudes and values (Paper Houses 130). In other words, what a feminist critique reveals about the damage done to women by patriarchal frameworks should not be dismissed in this attempt to show the possibility of female genius. It comes as no surprise that when Roberts engages-for example with the Church's account of Jesus' dis/ embodiment-the encounter is often profoundly disturbing and painful. However, the temptation from the feminist perspective, at this point, is to see Roberts' experience in almost entirely negative terms-simply one more illustration of that female situation or condition in which women are reduced, in Kristeva's words, to "fuming against metaphysics" along with Beauvoir because they seem to be confined within her analysis of woman as "the Other", merely defining the male: "in order to posit her a facticity and immanence and to refuse her access to true humanity, the humanity of autonomy and freedom" (Colette 405). I would argue it is too simplistic to suggest that the Christianity of Roberts' childhood ceased to be important to her as an adult-however problematically_or that she was only able to be a creative writer in so far as she could escape from its framing. This, it seems to me, is to fall back into Beauvoir's mind-set in The Second Sex, paradoxically colluding in that exclusion by definition, against which she otherwise struggled so relentlessly. I would suggest instead, that Roberts' journey towards female genius comes about through continuing engagement with the personal and theological relationships of the patriarchal Church that feminist theory has often cast in such a hostile light-and not without cause. This engagement can be seen as a kind of thinking that does not bracket off female desire or the pleasures of writing. We can say that it is the act of female genius to envisage an alternative: "to imagine a Christianity which was inspired by women as much as by men." (Secret Gospel 9). In other words, female genius is achieved in the pleasures of dialogue with these problematic structures, just as much as in any straightforward repudiation. She does not need even to be a feminist. Of course, it is clear, nevertheless, that Roberts was influenced by contemporary feminist theory and theology (Paper Houses 69); that she fell in love with feminism (Paper Houses 35). However, in Julia Kristeva's trilogy, Female Genius,

7 The Wild Girl was first published in 1984 with Methuen. An edition under a new title, The Secret Gospel of Mary Magdalene, with a new preface was published by Vintage Books in 2007. 
Arendt, Klein and Colette "manifested their freedom to explore without heeding the dominant trends, institutions, parties or schools of thought" (Arendt xix). My case for calling Roberts a female genius does not rest on her ideological perspective, so much as on her willingness to continue writing and to raise questions when she encounters limitations on her freedom to think, form new relationships or bring projects to birth even as she grapples with the pressures to bracket off aspects of herself that had been deemed unacceptably feminine within a normatively masculine framework.

\section{WiLd GirL/SECRET GOSPEL}

In The Wild Girl, Roberts seems to imply, beyond mere critique, that there is something more to Christianity than patriarchy; an idea she may have begun to form at University, when she worked on some notable medieval women mystics including Margery Kempe, Julian of Norwich and Mechtild of Magdeburg and recognized that their mystical and theological insights were achieved without conformity to male theologians or in accordance with the authority of ordained clergy (Paper Houses 11). Arguably then, it is in the spirit of these women, as well as under the influence of second wave feminism-about which she began to read after graduation (Paper Houses 69) - that she writes her novel, The Wild Girl, which implicitly questions some fundamental patriarchal assumptions about the nature of God and divine incarnation but does so from the singular perspective of a woman who writes for the sustaining pleasure it gives her. Of course, the book takes on board the findings of an emerging feminist biblical scholarship in the 1970s and 80 s with which Roberts was acquainted, through friends ${ }^{8}$ and her own reading, particularly of Elaine Pagels' work on the Gnostic Gospels. ${ }^{9}$ As a student Roberts had read M.R. James' The Apocryphal New Testament, liking "its smell of heresy, of banned stories" (Paper Houses 11) but the idea of banned Christian texts specifically concerning or written by women in the earliest centuries of the Christian era, gained wider currency with the publication of Pagels' work on the Nag Hammadi texts. Pagels' work, informed by stirrings in feminist theory, helped to familiarise a wider readership with texts such as the Gnostic Gospel of Mary in which Mary appeared to play a more prominent role than canonical biblical exegesis allowed. In identifying the wild girl of her novel with the reformed prostitute tradition-

For example, novelist and theologian, Sarah Maitland (Paper Houses 130).

9 The Nag Hammadi library about which Pagels writes and within which the texts that particularly inspired Roberts' novel, The Wild Girl, can be found, comprises 52 texts which were recovered from caves in the Jabal al-Tãrif mountain near the town of Nag 'Hammãdi in 1945 . Work on the texts suggests that some may date from as early as the $2^{\text {nd }}$ century CE. 
ally associated with Mary Magdalene, Roberts deliberately took issue with the Church's practice of reducing women to the polarity of holy sexless mothers and bad sexy whores (Secret Gospel 9) and here there is no denying the feminist tone. In the Author's note (in both 1984 and 2007 editions) to The Wild Girl, for example, Roberts acknowledges the influence of the Nag Hammadi texts and particularly "Thunder, Perfect Mind" on this novel and makes explicit reference to the evidence that, in $4^{\text {th }}$ century Egypt, their use was officially discourage ${ }^{10}$ implying that they had been read and valued before that date and valued enough in some part or parts of the Christian community for the copies that were discovered in the 1940s to have been carefully preserved. Feminist reading prompts Roberts to speculate imaginatively that in the early Church some significance aside from sinful materiality may have been associated with women and the feminine, and to construct her novel on that basis. In the preface to the 1984 novel, Roberts cites the comments of her friend-writer and feminist theologian Sarah Maitland-that contemporary theological scholarship agrees the Gospels "are not simple reportage but the first attempts at theology" (qtd. in Wild Girl 9), to indicate that in writing this novel, she was, at one and the same time attempting to dissect and recreate a myth. Like Kristeva's female geniuses, she strives to achieve her position as subject, by formulating a new theological relationship through the pleasures of writing that answers to her own needs rather than those of the malestream. In doing this, however, The Wild Girl was also drawing the New Testament narrative of Jesus into relationship with the preoccupations of Roberts' own life in London in the 1970s and 80s characterized by changing sexual mores and gender roles, a new emphasis on materiality and lifestyles which drew on psychoanalysis or non-Western traditions that seemed less ambivalent about the female body than traditional Christianity. Heather Walton proposes the feminist suggestion that by making Jesus and Mary Magdalene lovers:

Roberts touches the place of pain women experience in relation to the eradication of female sexuality from the dominant tradition. ... In the process she re-visions divine and human authority and presents male and female existence as potentially harmonious; capable of generating interpenetrating erotic pleasure rather than perpetual enmity. (Walton 81-82).

Some readers loved The Wild Girl and, predictably, some were offended. ${ }^{11}$ For Roberts, however, even more than make an ideologically feminist

10 Athanasius of Alexandria's Easter letter in 367 called for apocryphal writings to be eliminated from all the monastery libraries in Egypt. See, Meyer, ed. (xiii).

${ }_{11}$ There was an attempt to get the British publishers Methuen prosecuted for blasphemous libel and Roberts received her share of hate mail (Paper Houses 264). 
point, it confirmed her in her own mind as a writer. Writing was not a substitute for living but - as the work of female genius-it made living possible; it rooted her as subject in the work of representing the misogyny of the Christian Church and bringing it into question. Through her writing she could identify and resist the kind of bracketing and exclusion that had been so prominent an element of her previous experience of Christianity, come to some clearer understanding of theology/God-talk, and live more freely (Paper Houses 217).

So The Wild Girl expresses Roberts' singular commitment to her own pleasures, ambitions and curiosity. In the energetic struggling with language "repeatedly diving into the unconscious to find new forms, new stories, new meanings of words" (Paper Houses 217) she found her anchorage, writing her pleasure and using this as a means of negotiating the currents within a context characterized but not exhausted by the tenets of feminist criticism. In form, the narrative of The Wild Girl partakes of a traditional feminist strategy of "revision" familiar from the theoretical work of Adrienne Rich for example ("When We Dead Awaken" 1971) whereby old texts and narratives are read against the grain of existing patriarchal interpretations. Today, feminist theologians and critics may be more wary of attempting to re-read the existing traditions-however resistantly-for fear of contributing to essentially conservative forces by privileging their mythic forms (Walton 86) and this may be a warning well taken. Yet for Roberts in the early 1980s, this was her way of suggesting new kinds of relationships to address the particularity of her own challenges. For example, in accordance-after Beauvoir-with the feminist construction of women as outside or beyond the normative perspective, Roberts paints a picture of female potential "at the margins." On the refuse heaps created by masculinist exclusions, women do not simply endure but create and give life to the unexpected and the unforeseen. In one of Roberts' accounts of her character Mary's dreams, the destructive energy of fire and the promise of new life are combined in a vision of a burning refuse tip: "On the top of the [great heap of rubbish] which had become a pyre someone had abandoned a baby, a tiny girl who began to cry...." (Wild Girl 17). Writing the story of a sexy, holy woman, Roberts voices her objections to Christian representations of Christ, of women and of Gospel offered throughout her formative convent education, but seeks through the pleasures of writing to shift us into a new framework within which, in her project, relationships between God and humankind, men and women can be seen differently. The heterogeneous mixture of colours, sounds and moods in old-biblical_-stories and newly voiced-female-priorities kindled in the writing, are like the steaming, smoking refuse heap Roberts describes in the passage referred to above, digesting recognisable forms of language, thought 
and relationships, to produce the odour of decay but also fire for cleansing and fertile ground for new writing.

As I have already said, however, this is not to ignore the constraints or the implicit violence of either Roberts' context in the London of the 1970s and 1980s nor of her own responses. Roberts knows that female bodies continue literally to be thrown onto the rubbish heap behind the sacrificial altars of patriarchal and misogynistic idealisations and Heather Walton notes in relation to some of Roberts' other novels that concern themselves with Christian and theological themes, that some of Roberts' later work appears to express "a sense of irrecoverable loss" (Walton 84). Nevertheless, though her story about Mary describes the limitations she imagines would be faced by the first century woman who felt called to take a role of leadership in the movement led by Jesus, she is also, as both protagonist and author, taking on the role of theologian, concerned with finding new ways to find meaning as well as to talk about God, Christianity and the Church. Roberts draws on the Gnostic theologies of the Nag Hammadi library and other Apocryphal texts but expands the hints they give about gender as symbolic framework. She plays with the idea of the originary divine fullness or pleroma ${ }^{12}$ and with the mythic dramas that speak about falling or splitting and ultimately healing and returning to fullness. She weaves the story of Mary, as a first century wild child, into the Gospel accounts of Jesus' ministry, passion and death, augmenting it with a resurrection appearance based on the account in the Gospel of John and an apocryphal account of Mary Magdalene's attempts to explain her final encounter with the risen Lord to the rest of the disciples.

Roberts expresses her theological response to these issues, drawing on Gnostic and apocalyptic imagery explored in another series of dream sequences. In the first dream sequence, in which she focuses on the story of creation, Ignorance, the son of Sophia, is like the Gnostic demiurge of the Valentinian myth. Charged with the manual labour of creation by higher powers, he imagines that he is God and forgets his own created nature. He forgets his own origins in a larger divine fullness, typically represented in Roberts' novel through the imagery of marriage or sexual encounter. We might want to critique its implicit heterosexism but it succeeds in counterbalancing masculine singularity with the feminine, in a material and embodied as well as in a spiritual sense. In interpreting the dream, Jesus tells Mary that creation is an ongoing process in which differenthere male and female-forms of knowledge are involved. The nature of the story as concerned with a "fall" of some kind points to the consequences

12 This idea is addressed, for example, in the Tripartite Tractate-a treatise of Valentinian theology included in Nag Hammadi Texts. (Meyer ed. 45-84; 685-88). 
for God's people, of ignoring the dual nature of God as both masculine and feminine (Wild Girl 82) and of forgetting-the work of the children of Ignorance-what they originally knew.

Mary's dream visions remain dark and chaotic and that is hardly surprising. Though Roberts is benefiting from the work of earlier feminist writers, her thoughts must still have seemed somewhat outrageous when she listened with the ear of the dominant culture and the work, though pleasurable to a degree that sustained her writing, had to be undertaken without any complete confidence that she would be taken seriously. Her fears as author working in her "writer's garrett" in London, are reflected in her vision of Mary, in a tiny first century community, no longer supported by the earthly presence of Jesus, facing the suspicion and scorn of people to whom she feels obliged to speak about the unaccountable vision of divine and feminine fullness she and Jesus had explored together. Dream sequences take on an apocalyptic character. As Mary/Roberts struggles to give shape to her dreams, she draws on the extreme violence of the biblical book of Revelation to express the level of difficulty that would be required to rid men and women of the visions the Christian Churches have fed them under the influence of Ignorance. Mary faces up to the "red mist" of her "bloodlust and desire for revenge" directed by her feminine persona at the anti-Christ who, in a final, revelatory collapse, she recognises as "naked and vulnerable" simply a man, stretching out his arms towards her and all the other injured women of history (Wild Girl 173).

In the final sequence of the book, Roberts is neither defiant nor triumphalist. She clearly believes there is still enough female suffering at the hands of men in the twentieth century, not to speak of all there has been in the past, to justify the words she puts into the mouths of the women who attend the apocalyptic judgement of men (Wild Girl 172). Nevertheless, she closes with Mary's words of restraint and perplexity, concerning the book she had written about the best and the worst the world had to offer women:

I do not want this book to cause outrage, I do not want my work to lead anyone into danger. I shall carry with me in my heart the words that I must speak in future, and I shall leave these words buried under the tree, to ripen there or to rot. It seems to me that ideas are dangerous. Have not my visions taught me how we are willing to kill each other for the sake of an idea, for the sake of keeping a dream pure and intact? Yet, too, the force of Ignorance is an equal danger, and my mission, as I heard it plainly in my dream, is to warn against Ignorance, and to preach an Idea. In this great tumult of soul, in this confusion, and with a divided mind, I shall depart, with a baggage of doubt. (Wild Girl 180) 
In this concluding sequence of The Wild Girl, there is uncertainty. In her own voice, in the preface, Roberts distinguishes her account as "poetic" rather than "scholarly" (Wild Girl 9). The notion of the "poetic" indicates, surely, not just a different mode of thought and creativity but also a similar lack of confidence about those categories within which I have placed her, that is as theologian. This would make sense. I have argued strongly that to be a female genius does not imply immunity at every point from the potentially malign influence of patriarchal culture so much as to engage with it, drawing on the maternal birthing body of the female geniuses' own energies and pleasures to fuel contestation and challenge and to forestall exclusive definition within that culture. A contemporary feminist critique has theorized the extreme difficulty of this in degrees not excluding the total silencing of erasure. Yet women like Roberts continue in numerous ways that we may see or we may not, to defy those limitations and arguably also to bring about transformations, not the least of which has been the development of feminist theory itself.

It has been my object so far to show how the work of the female genius who creates or births without reference to an exclusively masculine power of divinity, can be illustrated in the singular circumstances of individual lives, such as that of Michèle Roberts. In a world after Freud of course, the language of the unconscious comes naturally to Roberts and she links it consistently with her creative work. "Diving into the unconscious" brings her in contact with a realm that is chaotic and disturbing and in which she sometimes fears she will get lost (Paper Houses 126). Yet it is in engaging with this affective strangeness and discomfort through the process of writing-contesting inherited symbolic representations of Christianity for example-that she is able to give shape to energies and to think creatively. Writing and rebellion (Paper Houses 55) literally go hand in hand in her life as she gives up the certainties and securities of marriage or a settled career to experiment with Marxism and feminism, sexuality, foreign cities and countries and to explore and make sense of all this through writing.

\section{ConClusion}

Beauvoir concluded that women's lives had been "dispersed among the males, attached through residence, housework, economic condition and social standing to certain men-fathers or husbands for example-more firmly than they are to other women". ${ }^{13}$ At the same time I believe that women have not merely suffered but sometimes dealt with this fragmenta-

13 Beauvoir, Second Sex, p. 19. 
tion; creatively sustaining forms of resistance, tradition and connection in limiting circumstances. In this essay I argue that it is crucially important, in order to contest any lingering sense of male domination, not to gloss over the lives of women as if they must have failed because of these limiting circumstances.

Specifically in relation to those women who write to make sense of Christian theology, I have used the idea of female genius to suggest that the idea of their insignificance - or even absence-is an illusion produced by the normatively male context Beauvoir defined so acutely in The Second Sex. Whilst we can never forget that women have been driven into madness, ${ }^{14}$ some, perhaps many, have refused to discount desire and accept silence, pursuing in some way, an understanding of God on their own terms that of course include the struggle with a normative male perception of their worth. In these terms it is possible to see Roberts' work as an illustration of the subject position Beauvoir showed us was so hard to achieve and Kristeva describes as female genius. She is a writer, valuing the "hot pulse of [her] desire" (Impossible Saints 36) sufficiently sometimes to acknowledge that it confirms her as a female genius, genuinely involved in doing theology. And perhaps we see that insight given literary form, in Roberts' female character who awakens with terror to her own creativity - the passage with which this piece began.

\section{WORKS CITED}

Battersby, Christine. Gender and Genius: Towards a Femininst Aesthetics. London: Women's, 1994.

Beauvoir, Simone de. The Second Sex. Trans. and ed. H.M. Parshley. Harmondsworth: Penguin, 1972.

Gilbert, Sandra M. and Susan Gubar. The Madwoman in the Attic: The Woman Writer and the Nineteenth-Century Literary Imagination. New Haven \& London: Yale University Press, 1984.

Jasper, Alison. "Revolting Fantasies: Reviewing the Cinematic Image as Fruitful Ground for Creative, Theological Interpretations in the Company of Julia Kristeva." Theology and Literature: Rethinking Reader Responsibility. Ed. Gaye Williams Ortiz and Clara A.B. Joseph. New York and Basingstoke, Hampshire: Palgrave Macmillan, 2006.

Kristeva, Julia. Colette. Trans. Jane Marie Todd. New York and Chichester, West Sussex: Columbia University Press, 2004.

14 See, for example, Gilbert and Gubar, Madwoman in the Attic, 1984, for a classic treatment of this theme. 
---. Hannab Arendt. Trans. Ross Guberman. New York and Chichester, West Sussex: Columbia University Press, 2001.

---. Interview with Philippe Petit. Revolt, She Said. Trans. Brian O’Keeffe. Ed. Sylvère Lotringer. Semiotext(e) Foreign Agents Series, 2002. ---. New Maladies of the Soul. Trans. Ross Guberman. New York and Chichester, West Sussex: Columbia University Press, 1995.

Meyer, Mervin, ed. The Gnostic Gospels: The Sacred Writings of the Nag Hammadi Library, The Berlin Gnostic Codex and Codex Tchacos. London: Folio Society, MMVIII, 2007.

Pagels, Elaine. The Gnostic Gospels. Harmondsworth: Penguin, 1990.

Rich, Adrienne. "When We Dead Awaken," Adrienne Rich's Poetry and Prose. Selected and ed. Barbara Charlesworth Gelpi and Albert Gelpi. New York and London: Norton, 1993. 166-77.

Roberts, Michèle. Impossible Saints. London: Virago, 1998.

---. Paper Houses: A Memoir of the '70s and Beyond. London: Virago, 2007.

---. The Secret Gospel of Mary Magdalene. London: Vintage, 2007.

---. The Wild Girl. London: Methuen-Minerva, 1991.

Sjöholm, Cecilia. Kristeva $\&$ the Political. London and New York: Routledge, 2005.

Walton, Heather. Imagining Theology: Women, Writing and God. London, New York: Clark, 2007. 